\title{
Geneologi Gender pada Perempuan Pembuat Ikan Kering
}

\author{
Rusni \\ Syaribulan \\ Universitas Muhammadiyah Makassar \\ syaribulan@unismuh.ac.id \\ Nurdin \\ Universitas Muhammadiyah Makassar \\ nurdin@unismuh.ac.id
}

\begin{abstract}
ABSTRAK
Penelitian tentang Geneologi Gender Pada perempuan Pembuat Ikan Kering di Keluarahan Lappa Kecamatan Sinjai Utara Kabupaten Sinjai.Rumusan masalah dari penelitian ini adalah Bagaimanakah perkembangan gender pada perempuan pembuat ikan kering di Kelurahan Lappa Kecamatan Sinjai Utara Kabupaten Sinjai.Penelitian ini bertujuan untuk mengetahui perkembangan gender pada perempuan pembuat ikan kering di Kelurahan Lappa Kecamatan Sinjai Utara Kabupaten Sinjai. Jenis penelitian ini adalah metode kualitatif deskriptif, pengumpulan data digunakan dengan cara observasi, wawancara mendalam, teknik dokumentasi dari hasil foto dan arsip yang dimiliki oleh pemerintah setempat. Dalam penelitian ini, yang menjadi sasaran penelitian adalah perempuan pembuat ikan kering yang ada di Kelurahan Lappa Kecamatan Sinjai Timur Kabupaten Sinjai. Hasil penelitian ini menunjukkan bahwa, perkembangan gender tidak hanya di negara bagian barat saja, akan tetapi gender pun berkembang di Indonesia bahkan di daerah-daerah seperti yang terjadi di Kelurahan Lappa. Yang diketahui bahwa gender sudah berkembang dilihat dari banyaknya kaum perempuan yang bekerja di ranah publik, adanya pemahaman perempuan tentang kodratnya, pembagian kerja yang jelas dalam rumah tangga, dan perempuan tidak terbebani dengan pekerjaannya. Dan juga dengan melakukan pekerjaan di ranah publik sebagai pembuat ikan kering tersebut dapat meningkatkan ekonomi dalam keluarga perempuan pembuat ikan kering.
\end{abstract}

Kata Kunci : Geneologi gender, Perempuan, Ikan Kering.

\section{PENDAHULUAN}

West, Candace and Zimmerman, dalam (Sugihastuti, 2010:4), mengatakan bahwa istilah gender muncul menjelang abad ke-20. Istilah gender pada awalnya dikembangkan sebagai analisis ilmu sosial. Gender bukanlah sesuatu yang kita dapatkan semenjak lahir dan bukanlah juga sesuatu yang kita miliki, melainkan sesuatu yang kita lakukan. Nugroho (2008:33), mengemukakan gender juga bukanlah kodrat ataupun ketentuan Tuhan, oleh karena itu gender berkaitan dengan proses keyakinan bagaimana seharusnya laki-laki dan perempuan berperan dan bertindak sesuai dengan tata nilai yang terstruktur, ketentuan sosial dan budaya ditempat mereka berada.

Sementara itu Engels dalam Narwoko (2011:335), menjelaskan perbedaan gender antara laki-laki dan perempuan terjadi melalui proses yang sangat panjang, 
melalui proses sosialisasi, penguatan, dan kontruksi sosial, kultural, dan keagamaan, bahkan melalui kekuasaan negara. Oleh karena itu, melalui proses yang panjang itulah, maka lama kelamaan perbedaan gender antara laki-laki dan perempuan seolah-olah menjadi ketentuan Tuhan atau kodrat dan tidak dapat diubah lagi. Dengan demikian gender sebagai suatu konsep merupakan hasil pemikiran atau rekayasa manusia, dibentuk oleh masyarakat sehingga gender bersifat dinamis dapat berbeda karena perbedaan adat istiadat, budaya, agama, dan sistem nilai dari bangsa, masyarakat dan suku bangsa tertentu.

Kedudukan dan peranan perempuan-perempuan di Indonesia telah tampak sejak zaman kerajaan sampai sekarang ini.Peranan perempuan Indonesia cukup beragam disebabkan oleh perbedaan tingkat peradaban kebudayaan berbagai suku bangsa dan pola-pola kehidupan masyarakat. Secara hukum perempuan di Indonesia berpeluang sama dengan laki-laki untuk berprestasi sesuai dengan potensinya dalam proses pembangunan, ditegaskan dalam UUD 1945 (pasal 27) mengenai kesamaan hak dan kewajiban bagi penduduk, tanpa membedakan laki-laki dan perempuan seperti di bidang kesehatan, hak perempuan, hukum, politik dan pekerjaan.

Meningkatnya partisipasi aktif perempuan dalam bidang pembangunan, ketahanan mental dan spiritual serta kemampuan dan kesempatan dalam semua bidang merupakan sasaran utama bagi terlaksananya secara efektif peranan perempuan dalam pembangunan.Dalam semua kesempatan perempuan dapat berperan aktif secara maksimal sebagai mitra sejajar laki-laki dalam masyarakat dan keluarga dengan sikap saling menghargai, saling menghormati, saling mengisi dan membantu.

Abdullah dalam Abdullah (2010:3), menjelaskan bahwa meningkatnya keterlibatan perempuan dalam kegiatan ekonomi ditandai dengan meningkatnya jumlah perempuan yang terlihat dalam pekerjaan diluar rumah tangga (outdoor activities).Hal ini, dapat dilihat dari kenaikan tingkat partisipasi perempuan dari waktu ke waktu.Peningkatan dalam jumlah bidang pekerjaan yang dapat dimasuki perempuan dimana sebelumnya bidang-bidang tersebut masih didominasi oleh laki-laki berangsurangsur dimasuki atau bahkan mulai didominasi oleh perempuan.Keterlibatan perempuan dalam berbagai bidang pekerjaan menjadi gejala yang mencolok tahun 1980-an.

Perkembangan hal diatas menunjukkan bahwa kesempatan-kesempatan semakin terbuka bagi perempuan dan sangat berarti untuk menganalisis makna perkembangan tersebut, baik bagi perempuan, laki-laki maupun masyarakat secara umum.Melihat kenyataan mengenai penduduk Indonesia, dimana separuhnya adalah kaum perempuan, 
diantaranya berstatus sebagai istri atau ibu rumah tangga merupakan salah satu potensi atau sumber modal dalam pembangunan.

Peran aktif perempuan dalam perekonomian keluarga tidak hanya ditujukan pada kaum yang berada di perkotaan tetapi juga menyentuh pada kaum perempuan yang berada di pedesaan yang sangat termarginalkan oleh budaya yang mereka anut. Perempuan dengan bekerja akan mengurangi kegiatan-kegiatan perempuan yang tidak berguna, mengurangi kejenuhan mereka ketika tidak bekerja, perempuan dengan bekerja juga akan memberikan tambahan pendapatan untuk memenuhi kekurangan ekonomi rumah tangganya, hal ini dijumpai pada perempuan pembuat ikan kering di Kelurahan Lappa Kecamatan Sinjai Utara Kabupaten Sinjai. Dimana pada daerah tersebut, kaum perempuan turut serta dalam pembuatan ikan kering tidak lain untuk membantu suami mereka untuk memenuhi kebutuhan ekonomi keluarga dan mengimplementasikan keinginan mereka untuk melakukan pekerjaan, selain dari pekerjaan dapur dan mengurus rumah tangga akan tetapi pekerjaan di luar rumah atau pekerjaan publik. Disinilah kita melihat bahwa gender tidak hanya berkembang di perkotaan akan tetapi gender pun sudah mulai berkembang di pedesaan, dan daerah pesisir.

\section{LANDASAN TEORI}

Nugroho (2011:2), istilah gender pertama kali diperkenalkan oleh Robert Stoller (1968), untuk memisahkan pencirian manusia yang didasarkan pada pendefenisian yang bersifat sosial budaya dengan pendefenisian dari ciri-ciri fisik biologis. Nugroho (2011:1), mengemukakan bahwa kata gender dalam istilah bahasa Indonesia sebenarnya berasal dari bahasa Inggris, yaitu ' gender'. Jika dilihat dalam kamus bahasa Inggris, tidak secara jelas dibedakan pengertian antara sex dan gender. Untuk memahami konsep gender maka harus dapat dibedakan antara kata gender dengan seks. Pengertian seks (jenis kelamin) merupakan pembagian dua jenis kelamin tertentu.Misalnya, bahwa manusia yang jenis kelamin laki-laki adalah manusia yang memiliki penis, memiliki jakala, dan memproduksi sperma.Sedangkan perempuan memiliki alat reproduksi, seperti rahim dan saluran untuk melahirkan, memproduksi sel telur, memiliki vagina, dan mempunyai alat untuk menyusui.Hal tersebut melekat pada perempuan dan lakilaki.Artinya bahwa secara biologis alat-alat tersebut tidak dapat dipertukarkan antara alat biologis yang melekat pada manusia laki-laki dan perempuan.Secara permanen tidak berubah dan merupakan ketentuan biologis atau sering dikatakan sebagai kodrat (ketentuan Tuhan). 
Setiadi (2011:873), gender merupakan istilah istilah yang digunakan untuk membedakan antara laki-laki dan perempuan yang didasarkan pada aspek sosiokultural. Jenis kelamin terbentuk melalui proses alamiah dan bersifat kodrat ilahiah, sedangkan gender merupakan atribut dan perilaku yang terbentuk melalui proses sosial, sehinga istilah gender lebih merujuk pada bangunan kultural yang acap kali masalah atau isu yang berkaitan dengan peran, perilaku, tugas, hak, dan fungsi yang dibebankan kepada perempuan dan laki-laki.

Sedangkan Judith Butler dalam Nugroho (2008:33), juga memberikan argumentasinya bahwa gender merupakan bentuk simbolik dari aksi masyarakat yang mengikuti kebiasaan yang dilakukan. Selanjutnya Butler menyebutkan bahwa gender adalah sebuah identitas yang dibentuk oleh waktu, dilembagakan dalam suatu eksteriorruang melalui serangkaian kegiatan khas (stylized repetitionof acts) yang berulang. Efek dari gender diproduksi melalui kegiatan khas tersebut yang akhirnya membentuk ilusi-ilusi yang mengikat sang diri gender itu sendiri. Bebicara tentang gender tidak terlepas dari pembahasan tentang feminisme, kata feminis pertama kali ditemukan pada awal abad ke-19 oleh seorang sosialis berkebangsaan Perancis, yaitu Charles Fourier. Terdapat perbedaan pendapat antara ilmuan tentang sejarah munculnya istilah feminisme. Pendapat pertama menyatakan bahwa Istilah Feminisme berasal dari bahasa Latin Femina (perempuan). Hamid Fahmy Zarkasi mengutip pendapat Ruth Tucker dan Walter Liefeld dalam buku mereka yang berjudul Daughter of the Church yang menyatakan bahwa kata istilah feminis berasal dari kata fe atau fides dan minus yang artinya kurang iman (less in faith).

Nugroho (2011:87), mengatakan bahwa tak dapat dipungkiri munculnya gerakan perempuan di belahan dunia lain membawa imbas pengaruh ke dalam nuansa pergerakan perempuan di Indonesia. Pengaruh tadi dapat kita lihat dalam bentuk munculnya ide-ide emansipatif oleh Kartini ataupun strategi perjuangan organisasiorganisasi perempuan untuk berusaha menekan keluarnya undang-undang perkawinan pada dekade 1950-an yang mengambil model perjuangan feminis liberal khususnya dalam perjuangan reformasi hukum. Seiring dengan perubahan zaman maka fokus perjuangan gerakan perempuan Indonesia itu kemudian berkembang pada isu-isu genderseperti masalah peran ganda, isu perkosaan, aborsi, serta berbagai isu gender lainnya.

Setiadi (2011:876), persoalan gender di Indonesia dapat dilihat dari aspek ruang dan waktu atas dasar kultur yang berlaku di berbagai lokasi dan waktu tertentu. Pada 
masa lalu kultur budaya Jawa menempatkan kaum perempuan sebagai kaum yang memiliki hak-hak sosial yang lebih sempit dibandingkan laki-laki. Kaum perempuan sebagai sosok kaum yang ditempatkan sebagai kelompok yang dipingit dalam rumah, tiak boleh belajar di luar rumah, tidak boleh bekerja di luar rumah, dan tidak boleh mengenyam pendidikan. Demikian juga kultur Jawa menempatkan kaum perempuan terhadap pembagian hak waris keluarga dengan rumus segendong sepikul atau satu banding setengah.

Begitupun di Sinjai setelah gender berkembang di barat dan di Indonesia maka gender pun berkembang di Kabupaten Sinjai.Dimana diketahui bahwa dahulu masyarakat Sinjai masih menganut sistem kerajaan diman kaum perempuan tidak diperbolehkan untuk menuntut pendidikan yang tinggi ataupun bekerja di luar rumah.Karena masyarakat dahulu menganggap bahwa sudah menjadi kodrat perempuan untuk bekerja dalam rumah saja, mengasuh anak, mengurus rumah tangga.Seiring dengan perkembangan zaman, dan banyaknya kaum perempuan yang memperjuangkan nasib kaum perempuan maka nasib kaum perempuan di Sinjai sudah berubah.Perempuan di Sinjai sudah keluar untuk menuntut pendidikan, berja di luar rumah dan tidak lagi ditekan oleh budaya yang mereka anut.

Soerjono Soekanto (2013:143), masyarakat adalah masyarakat yang bertempat tinggal di suatu wilayah (geografis) dengan batas-batas tertentu, dimana faktor utama yang menjadi dasarnya adalah interaksi yang lebih besar diantara anggota, dibandingkan dengan interkasi dengan penduduk di luar batas wilayahnya. Selanjutnya masyarakat pesisir dalam Satria (2014:1) mengatakan bahwa masyarakat pesisir adalah sekumpulan masyarakat yang hidup bersama-sama mendiami wilayah pesisir dan memiliki kebudayaan yang khas yang terkait dengan ketergantugannya pada pemanfaatan sumber daya pesisir.Tentu saja masyarakat pesisir bukan saja nelayan, melainkan pembudidaya ikan, pengolah ikan bahkan pedagang ikan serta pembuat ikan kering.

Adapun teori yang digunakan dalam membahas penelitian ini yaitu teori fungsionalisme dalam feminisme dimana dalam teori ini dijelaskan bahwa konsep gender bukan melahirkan pertentangan atas dasar ketidakadilan akan tetapi, lebih menekankan pada pembagian peran dan fungsi masing-masing antara laki-laki dan perempuan agar tecipta keharmonisan antara laki-laki dan perempuan. Kemudian yang kedua yaitu teori nature, dimana teori tersebut meganggap bahwa peran antara laki-laki dan perempuan bersifat kodrati.Anatomi biologis antara laki-laki dan perempuan yang berbeda menjadi faktor utama dalam penentuan peran sosial kedua jenis kelamin ini.Laki-laki memiliki 
peran lebih utama dalam masyarakat karena dianggap lebih kuat, lebih potensial, dan lebih produktif.Sementara perempuan dianggap lemah, itulah yang menybabkan sehingga menimbulkan pemisahan fungsi antara laki-laki dan perempuan dimana pada penelitian ini pekerjaan laki adalah sebagi nelayan karena dianggap lebih kuat sedangkan perempuan bekerja sebagai pembuat ikan kering karena dianggap pekerjaan tersebut tergolong pekerjaan yang lemah dan dapat dikerjakan oleh perempuan.

Selanjutnya teori yang ketiga yaitu teori nurture yang beranggapan bahwa perbedaan relasi gender antara laki-laki dan perempuan tidak ditentukan oleh faktor biologis melainkan oleh kontruksi masyarakat. Dengan perkataan lain bahwa menurut penganut paham nurture, peran sosial yang selama ini dianggap baku dan dipahami sebagai doktrin keagamaan, sesungguhnya bukanlah kehendak Tuhan dan tidak juga sebagai determinasi biologis melainkan sebagai produk kontruksi sosial. Itulah yang menyebabkan hingga saat ini meskipun perempuan sudah banyak yang bekerja di ranah publik mereka tetap dianggap bahwa laki-laki adalah kepala keluarga sehingga mereka dianggap sebagai pencari nafkah utamasedangkan perempuan adalah pencari nafkah kedua atau tambahan.

\section{METODE PENELITIAN}

Jenis penelitian yang dilakukan adalah penelitian kualitatif yaitu sebagai prosedur penelitian yang menghasilkan data deskriptif berupa kata-kata tertulis atau lisan dari orang-orang dan perilaku yang dapat diamati, yang bertujuan memahami perkembangan gender yang terjadi pada perempuan pembuat ikan kering yang ada di Kelurahan Lappa Kecamatan Sinjai Utara Kabupaten Sinjai. Informan ditentukan secara purposive sampling,fokus penelitian yaitu perempuan pembuat ikan kering yang ada di Kelurahan Lappa Kecamatan Sinjai Utara Kabupaten Sinjai. Yang bertindak sebagai instrumen penelitian adalah peneliti sendiri dengan menggunakan alat bantu berupa pedoman wawancara (daftar pertanyaan), pedoman observasi, pinsil/pulpen dan catatan peneliti yang berfungsi sebagai alat pengumpul data serta alat pemotert,teknik pengumpulan data yaitu observasi, wawancara, dan dokumentasi, kemudian dianalisis melalui tahap reduksi data, penyajian data, lalu kemudian penarikan kesimpulan. Adapun teknik keabsahan data untuk lebih mudah mempertanggungjawabkan hasil penelitian di lapangan yaitu dengan menggunakan yaitu dengan mengunakan metode triangulasi yakni triangulasi sumber, triangulasi teknik, dan triangulasi waktu. 


\section{PEMBAHASAN}

Perempuan pada umumnya dianggap(kontruksi sosial) sebagai seseorang yang pekerjaannya memang hanya di rumah mengurus rumah tangga tanpa diperbolehkan atau diberi kesempatan untuk bekerja di luar rumah, padahal perempuan juga memiliki kemampuan dan keterampilan. Inilah yang menyebabkan banyak perempuan-perempuan di Indonesia yang tidak diperbolehkan untuk mengenyam pendidikan yang teralalu tinggi, cukup perempuan tersebut dapat membaca dan menulis karena orang tua dan masyarakat menganggap bahwa pada akhirnya perempuan akan kembali ke dapur. Seorang perempuan tidak akan mendapatkan kursi di pemerintahan, tidak akan mendapatkan tempat di ranah publik, jadi percuma perempuan itu mengenyam pendidikan yang tinggi, hanya akan menghabiskan biaya saja tanpa ada tujuan yang jelas. Inilah pandanganpandangan masyarakat atau kontruksi sosial yang menyebabkan banyak perempuanperempuan yang terbelenggu dan terus-menerus tergantung kepada laki-laki.

Akan tetapi seiring dengan perkembangan zaman, muncullah konsep gender, yang pertama kali diperkenalkan oleh Robert Stoller pada tahun 1968 untuk memisahkan pencirian manusia yang didasarkan pada pendefenisian yang bersifat sosial budaya dengan pendefenisian dari ciri-ciri fisik biologis di negara barat. Kemudian muncullah gerakan-gerakan perempuan yang berusaha membebaskan perempuan dari belenggu dan ketergantungan kepada laki-laki.

Selanjutnya setelah genderdikenal di barat maka gender pun mulai dikenal di Indonesia, seperti yang kita ketahui banyak pelopor-pelopor perempuan yang dikenal sebagai pelopor perempuan yang selalu memperjuangkan nasib kaum perempuan seperti R.A. Kartini dan lain sebagainya. Dengan begitu perempuan di Indonesia pun mulai diizinkan untuk mengeyam pendidikan yang lebih tinggi, dan mulai diizinkan untuk bekerja di luar rumah.Hingga ke daerah-daerah kecil ataupun di pedesaan gerakan perempuan yang dilakukan oleh Kartini mulai dirasakan hasilnya.

Gender pun semakin berkembang seperti halnya di Kelurahan Lappa, yang dulunya pekerjaan seorang perempuan hanya bekerja di dapur saja, mengurus suami dan anak-anaknya, dan tidak diperbolehkan untuk bekerja di luar rumah.Akan tetapi, sekarang ini tidak lagi demikian, perempuan sekarang sudah diperbolehkan untuk mengenyam pendidikan yang lebih tinggi, dan diizinkan pula bekerja di luar rumah. Jadi sekarang ini, pekerjaan seorang perempuan tidak lagi hanya di rumah toh saja akan tetapi perempuan mulai bekerja di luar rumah sesuai dengan kemampuan dan keterampilan yang dimilikinya, seperti halnya pada perempuan pembuat ikan kering di Kelurahan Lappa 
tersebut. Tetapi, meskipun demikian perempuan tersebut tidak melupakan kodratnya, karena mereka memahami dengan jelas yang mana kodratnya yang tidak mungkin digantikan dengan laki-laki dan yang mana pekerjaan yang dapat digantikan atau dikerjakan oleh laki-laki.Begitupun dengan suaminya, selain mengizinkan untuk bekerja di luar rumah suami atau kepala rumah tangga pun selalu membantu pekerjaan istrinya dalam kesehariaanya apabila mereka tidak sedang melaut. Jadi, dalam setiap keluarga pada di daerah ini sudah terjalin kerja sama yang baik antara suami dan istri dalam rumah tangga mereka hingga dapat mencipatakan sebuah rumah tangga yang harmonis, hal ini betul sudah menunjukkan perkembangan gender pada daerah tersebut. dimana dalam satu pekerjaan tidak dibebankan kepada satu orang saja akan tetapi mereka bersama-sama dalam mengerjakannya. Kecuali peerjaan laki-laki yang memang tidak dapat dikerjakan oleh perempuan.Hal tersebut sesuai dengan teori fungsionalisme dalam feminisme yang menekankan pembagian peran dan fungsi yang jelas antara laki-laki dan perempuan dimana perempuan dan laki-laki sama-sama mencari nafkah di luar rumah dan saling membantu dalam rumah tangga.Kemudian menurut teori nature yang beranggapan bahwa laki-laki lebih kuat dibanding dengan perempuan sehingga laki-laki mengerjakan pekerjaan yang lebih berat dimana laki-laki atau suami bekerja sebagai nelayan sedangkan perempuan mengerjakan pekerjaan yang terolong ringan yaitu sebagai pembuat ikan kering. Sedangkan menurut teori nurture beranggapan bahwa perbedaan antara laki-laki dan perempuan itu hanyalah kontruksi sosial saja dan bukan merupakan kodrat Tuhan sehingga sekarang ini perempuan dianggap sebagai pencari nafkah kedua atau tambahan sedangkan laki-laki sebagai pencari nafkah utama.

Turut sertanya perempuan bekerja membantu suami mereka sebagai pembuat ikan kering itu dapat memberikan dampak positif terhadap kehidupan keluarga mereka dimana perempuan tersebut dapat meningkatkan perekonomian dalam rumah tangga mereka sehingga mampu pula menyekolahkan anak-anak mereka ke jenjang yang lebih tinggi dan kesehatan pun dapat terjamin.

\section{KESIMPULAN}

Perkembangan gender pada perempuan pembuat ikan kering dapat ditarik sebuah kesimpulan bahwa perkembangan gender tidak hanya terjadi di negara bagian barat akan tetapi gender pun berkembang di Indonesia, hingga sampai di daerah-daerah ataupun pedesaan. Seperti di Kelurahan Lappa sekarang ini sudah banyak perempuan yang turut serta bekerja di ranah publik, tanpa melupakan pekerjaan rumah mereka dan melupakan 
kodrat mereka sebagai perempuan.Dan dengan melakukan pekerjaan (membuat ikan kering) tersebut dapat meningkatkan perekonomian dalam rumah tangga mereka sehingga mereka dapat menyekolahkan anak-anak mereka ke jenjang sekolah yang lebih tinggi.

\section{DAFTAR PUSTAKA}

Agussalim,dkk. (2008). Ilmu Sosial Budaya Dasar Suatu Pendekatan Multidisiplin. Makassar: Universitas Negeri Makassar.

Garna, Judistira. (1996). Ilmu-Ilmu Sosial Dasar-Konsep-Posisi. Bandung: Program Pascasarjana Univrsitas Padjadjaran.

Moleong.(2007). Metodologi Penelitian Kualitatif. Bandung: PT Remaja Rosdakarya.

Narwoko, Dwi dan Suyanto, Bagong. (2011). Sosiologi Teks Pengantar dan Terapan. Jakarta: Kencana Prenada Media Group.

Nugroho, Riant. (2008). Gender dan Administrasi Publik. Yokyakarta: Pustaka Pelajar.

Nugroho, Riant (2011). Gender dan Strategi Pengarus-utamanya di Indonesia. Yokyakarta: Pustaka Pelajar.

Said, Abdullah.(2010). Peran Ganda Istri Komunitas Petani Padi di Desa Laro Kecamatan Burau Kabupaten Luwu Timur. Makassar: Proposal Sosiologi FKIP Unismuh Makassar.

Sari, Linda Amalia dan Suryamin.(2013). Pembangunan Manusia Berbasis Gender 2013. Jakarta: Kementerian Pemberdayaan Perempuan dan Perlindungan Anak.

Satria.(2014). Sosiologi Masyarakat Pesisir.(online) (http://Satria.blogspot.com/2014/03/sosiologi masyarakat pesisir. pdf, diakses 2 April 2015).

Setiadi, Elly M, dkk.(2012). Ilmu sosial dan Budaya Dasar. Bandung. Kencana Prenada Media Group.

Setiadi, Elly M,dan Kolip Usman. (2011). Pengantar Sosiologi. Jakarta: Kencana Prenada Media Group.

Smantos 355.(2012). Letak Geografis Kabupaten Sinjai. (online) http://smantostop.blogspot.com/2012/03/letakgeografis Kabupaten Sinjai. html\#sthash.GkEoJCNC.dpuf. Diakses 23 Mei 2015.

Soekanto, Soerjono dan Sulistyowati, Budi.(2013). Sosiologi Suatu Pengantar. Jakarata: PT Raja Grafindo Persada.

Sugihastuti dan Hadi, Septiawan Itsna.(2010). Gender dan Inferioritas Perempuan. Yokyakarta: Pustaka Pelajar. 
Sugiyono.(2012). Memahami Penelitian Kualitatif. Bandung. ALFABETA cv.

Sugiono.(2014). Metode Penelitian Kuantitatif Kualitatif dan R\&D. Bandung: ALVABETA, CV.

Sugiyono.(2015). Metode Penelitian Pendidikan (Pendekatan Kuantitatif, Kualitatif, dan $R \& D)$. Bandung:Alfabeta $\mathrm{CV}$.

Syamsuri, Andi Sukri, dkk. (2013). Pedoman Penulisan Skripsi. Makassar: FKIP Unismuh Makassar.

Tahir.(2014). Metode Penelitian.Makassar: FKIP Unismuh Makassar.

Upe Ambo. (2010). Tradisi Aliran Dalam Sosiologi Dari Filosofi Positivistik Ke PostPositivistik.Jakarta: PT Raja Grafindo Persada.

Warsito.(2006). Sejarah Muncul Dan BerkembangnyaFeminisme Dan Gender. (online) (http://warsito.Com gender.html, diakses 25 Maret 2015.) 